\title{
Pembrontakan terhadap pemerintahan yang sah (bugah) dalam perspektif hukum Islam
}

\author{
Sukring dan Rustam \\ Fakultas Hukum Universitas Halu Oleo Kendari \\ E-mail: sukring_69@yahoo.co.id. \\ DOI:10.18326/ijtihad.v16i1.67-83
}

Islam is Rahmatan lil 'Alamin religion, Islam loves peace and justice, Islam never teaches violence and corruption in the world. Along with global development and progress, the understanding of Islam teaching began to be degraded by some groups of Muslim, then came some groups that distort Islam religious teaching. There is a fundamental radical giving wrong interpretation to the religious teaching understanding. Then came terrorists and insurgents that against the legitimate government. Those who stay away from moderation will always cause the appearing of harsh and extreme groups in all time. The purpose of terrorists and insurgents is the destruction to the strength, power, stability, and safety of the nation. Hazard and press power of the insurgents against the government can not be tolerated. Because they commited treason against the legitimate government, the punishment for those who fight against Allah and his Messenger and who do mischief in the earth is killed and crucified or having their hands and feet cut in crossways, or exiled from his place. This article draws the condition of Muslim communities, especially in Islamic countries in the Middle East that are flaring up today.

Islam adalah agama rạ̣matan lil 'álamīn, Islam cinta kedamaian, dan keadilan, Islam tidak pernah mengajarkan kekerasan dan kerusakan di muka bumi. Seiring dengan perkembangan dan kemajuan global, pemahaman ajaran Islam mulai terdegradasi oleh sebagian kelompok umat Islam. Maka muncullah kelompok-kelompok yang mendistorsi ajaran agama Islam. Ada yang radikal, fundamental yang memberikan interpretasi yang keliru terhadap pemahaman ajaran agama sehingga muncullah kelompok teroris dan pemberontak terhadap pemerintah yang sah. Mereka yang menjauhkan diri dari sikap moderat, sepanjang zaman akan selalu muncul kelompok-kelompok yang berhaluan keras dan ekstrimis. Tujuan teroris dan pemberontak adalah penghancuran terhadap kekuatan, kekuasaan, stabilitas, serta keselamatan bangsa. Bahaya dan daya tekan pemberontak melawan pemerintah tidak bisa di tolerrir. Karena pemberomtak melakukan perbuatan makar terhadap Pemerintah yang sah. Maka hukuman bagi mereka yang memerangi Allah dan Rasul-Nya, dan membuat kerusakan di muka bumi hanyalah dibunuh dan 
ljtihad, Jurnal Wacana Hukum Islam dan Kemanusiaan, Volume 16, No. 1, Juni 2016: 67-83

disalib, atau di potong tangan dan kaki mereka secara silang, atau diasingkan dari tempat kediamannya. Tulisan ini diangkat berdasarkan kondisi masyarakat Muslim khusunya di negara-negara Islam di timur tengah yang saat ini sedang bergejolak.

Keywords: Rebelion; Legal government; Islamic law; Separatism

\section{Pendahuluan}

Saat ini, berbagai media massa ramai menyajikan berita demo besar-besaran anti pemerintah yang menyebabkan beberapa pemimpin negara di Timur Tengah dan Dunia Arab bertumbangan. Suriah, Mesir, Tunisia, Libya, Maroko, Bahrain, Yordania, Yaman, ribut dengan para penguasanya. Meski demo ini telah berhasil menggulingkan penguasa, namun dampak buruknya masih tampak nyata dan sangat terasa. Negara porak-poranda, nyawa melayang, bangunan rusak, rasa aman hilang, hidup dalam pengungsian karena kehilangan rumah, dan kerugian lainnya. Kerugian dan kerusakan sangat tampak nyata, sedangkan kebaikan dan perbaikan belum jelas wujudnya.

Oleh karena itu, jalan terbaik menghadapi penguasa zhalim adalah jalan yang telah digariskan oleh Rasulullah Saw. Bersabar, tidak memberontak, dan bagi orang-orang yang memiliki kemampuan berkewajiban memberikan nasehat secara rahasia. Karena pemberontakan hanya akan menambah kerusakan dan keburukan.

Sebagai rakyat, kita harus kembali kepada kebenaran, bertaubat, beribadah, dan memperbaiki diri. Karena kualitas pemimpin itu sesuai dengan rakyatnya. Sebagai penguasa, mereka harus menghindari sikap zhalim; Dia harus bersikap adil dan bijak, serta harus membawa kebaikan bagi rakyat. Jika tidak, maka siksa Allah yang maha dahsyat menunggunya. Karena setiap orang akan bertanggung jawab terhadap kewajibannya masing-masing.

Jika seorang penguasa yang zhalim berkuasa, seperti Yazid, Abdul Malik, al-Manshur, dan lainnya dikatakan bahwa Ia wajib diturunkan dari jabatannya dan ia wajib diperangi sampai ia diganti orang lain, sebagaimana dilakukan oleh orang-orang yang berpendapat memerangi penguasa zhalim itu boleh, maka yang jelas terwujud adalah kerusakan. Dan kerusakan (akibat memerangi penguasa zhalim) ini lebih besar dari kebaikannya. Orangorang yang memberontak hanya akan mendatangkan keburukan yang lebih besar daripada kebaikannya. Beberapa hadis berikut ini menjadi bahan intropeksi; 


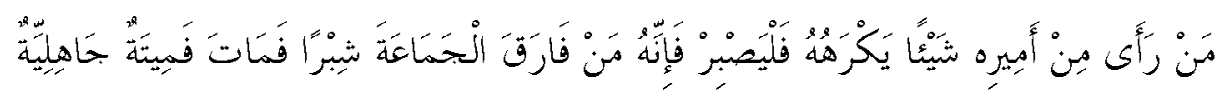

Artinya: "Barangsiapa yang melihat suatu (kemungkaran) yang ia benci pada pemimpinnya, maka hendaklah ia bersabar, karena sesungguhnya barangsiapa yang memisahkan diri dari jamaah (pemerintah) kemudian ia mati, maka matinya adalah mati jahiliyah." [HR. Al-Bukhari dan Muslim dari Abdullah bin Abbas radhiyallahu'anhuma]

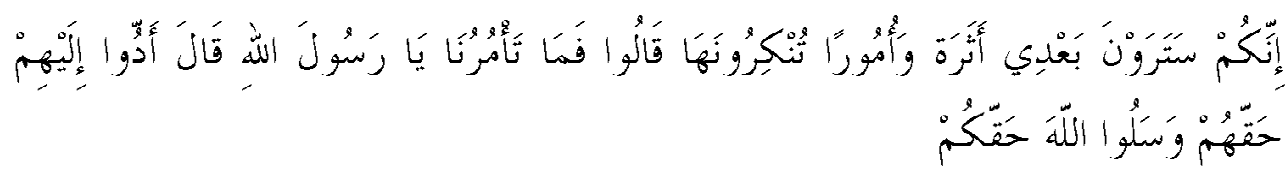

Artinya;"Sesungguhnya kalian akan melihat (pada pemimpin kalian) kecurangan dan halhal yang kalian ingkari (kemungkaran)". Mereka bertanya, "Apa yang engkau perintahkan kepada kami wahai Rasulullah?” Beliau menjawab: "Tunaikan hak mereka (pemimpin) dan mintalah kepada Allah hak kalian." [HR. Al-Bukhari dan Muslim dari Abdullah bin Mas'ud radhiyallahu'anhu]

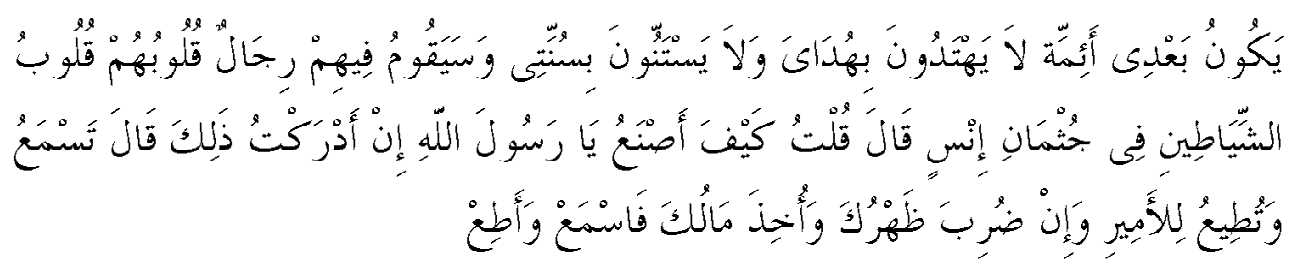

Artinya;"Akan ada sepeninggalku para penguasa yang tidak meneladani petunjukku dan tidak mengamalkan sunnahku, dan akan muncul diantara mereka (para penguasa) orang-orang yang hati-hati mereka adalah hati-hati setan dalam jasad manusia." Aku (Hudzaifah) berkata, "Bagaimana aku harus bersikap jika aku mengalami hal seperti ini?" Rasulullah shallallahu'alaihi wa sallam bersabda, "Engkau tetap dengar dan taat kepada pemimpin itu, meskipun punggungmu dipukul dan hartamu diambil, maka dengar dan taatlah.” [HR. Muslim dari Hudzaifah Ibnul Yaman radhiyallahu’anhu]

Dan akhir dari para pemberontak ini, mungkin kalah atau mungkin menang, namun kekuasaan mereka akan segera hilang, sehingga tidak berakhir dengan baik. Contohnya seperti Abdullah bin Ali dan Abu Muslim, keduanya telah membunuh banyak orang (dalam pemberontakannya), namun keduanya dibunuh oleh Abu Ja'far al-Manshûr. Adapun penduduk Harrah (Madinah), Ibnul Asy'ats, Ibnul Muhallab, dan lainnya, mereka berhasil 
ljtihad, Jurnal Wacana Hukum Islam dan Kemanusiaan, Volume 16, No. 1, Juni 2016: 67-83

ditumpas beserta para pengikutnya. Sehingga mereka itu tidak bisa menegakkan agama dan tidak bisa melestarikan dunia. Padahal Allâh tidak memerintahkan suatu perintah yang tidak mewujudkan kebaikan agama dan kebaikan dunia. Walaupun pelaku (pemberontakan) itu termasuk wali-wali Allâh yang bertaqwa dan penduduk surga tetapi mereka tidak lebih mulia daripada 'Ali, 'Aisyah, Thalhah, al-Zubair Radhizallahu anbum dan lainnya. Meski demikian, mereka ini tidak dipuji atas peperangan yang telah mereka lakukan, padahal mereka ini lebih agung kedudukannya di sisi Allâh dan lebih baik niatnya dibandingkan yang lain. Juga penduduk Madinah, di kalangan mereka (yang memberontak terhadap Yazid) banyak ahli ilmu dan agama. Demikian juga para pengikut al-Asy'ari, ada banyak ahli ilmu dan agama. Sejarah terulang kembali di abad modern ini, maraknya pemberontakan di dunia Islam, membuat penulis terinspirasi untuk melakukan kajian tentang "Pemberontakan terhadap pemerintahan yang tidak secara terang-terangan melakukan kemusyrikan bertentangan dengan hukum Islam".

\section{Arti pemberontakan secara bahasa}

Dalam bahasa Arab, yang sepadan maknanya dengan pemberontakan adalah بغي (baqyu) yang terkadang menyiratkan hasrat hawa nafsu, sikap berlebihan atau kadang bermakna penindasan. Menurut para fuqabā (ahli hukum), pemberontakan berarti melanggar hukum pemerintah yang sah, kemudian melancarkan serangan bersenjata kepada mereka.

Seorang filolog yang bernama Ibnu Faris, berkata; kata baqyun terdiri dari huruf ba', gain dan $y a$ ' memiliki dua makna. Salah satunya adalah bermakna mencari sesuatu. Kedua adalah satu jenis kerusakan. Makna kedua ini seperti kalimat "bagāa al-jarbu”" (luka itu tambah parah) kemudian terbentuk dari kata ini makna-makna selanjutnya. Al-bagyu berarti juga kejahatan. Contohnya, seseorang berbuat jahat kepada orang lain, apabila dia merupakan pelaku kejahatan, maka akan timbul darinya kejahatan, sehingga al-bagbyu berarti juga kezaliman (Faris, 2002: 144).

Sedangkan Ibnu Nujaim mendefinisikan pemberontakan dengan kata al-buqāt adalah bentuk jamak dari kata baghà 'alàn nāa (berbuat zalim dan melewati batas kepada orang lain). Dari kata baghyun berarti melakukan kerusakan. Contohnya al-fiqah al-baghbiyah, kelompok yang melakukan kerusakan. Kelompok ini telah melenceng dari tujuannya dan disebut 
kelompok yang melenceng, karena kelompok ini telah membelot dari ketaatan pada pemimpin yang sah (Nujaim, t.th.: 150).

Kajian semantik mendalam seperti ini dijelaskan juga dalam kamus-kamus bahasa Arab seperti Tahdhïb al-Luqah, al-Shị̣ah, dan Lisān al-Arab. Definisi klasikal ini membuktikan bahwa kata "pemberontakan" berarti penindasan dan tindakan berlebihan, lebih jauh lagi, kata ini juga merujuk pada tindakan melanggar hal-hal yang bersifat legal, konstitusional, serta batasan hukum dengan tujuan menyebarkan konflik, kerusakan dn kekacauan dalam ranah sosial.

\section{Pengertian pemberontakan menurut Syar'i}

Ibnu Humam merumuskan definisi pembrontakan yang cukup lengkap, dan menjelaskan macam-macam corak pemberontakan. Kata al-bāgyu menurut tradisi para ahli fiqih artinya membelot dari ketaatan kepada pemimpin yang sah. Adapun para pembelot itu ada empat jenis, yaitu; Pertama, pembelot yang tidak memiliki interpretasi sendiri atau tanpa kekuatan militer. Mereka merampas harta orang lain dan membunuhnya, serta melakukan teror jalanan, mereka disebut perampok. Kedua, komunitas seperti yang pertama hanya mereka tidak memiliki kekuatan militer, tetapi memiliki interpretasi sendiri. Maka hukum atas mereka sama seperti perampok. Jika mereka melakukan pembunuhan, maka harus dibunuh dan di salib. Jika mereka merampas harta orang-orang muslim, maka tangan dan kaki mereka harus dipotong. Ketiga, komunitas pembelot yang memiliki kekuatan dan pertahanan militer dan interpretasi sendiri bahwa imam itu batil dan kufur atau melakukan maksiat serta wajib diperangi. Mereka adalah kelompok Khawarij yang menghalalkan darah dan harta kaum muslimin. Menawan kaum wanitanya dan menganggap kafir para sahabat Rasulullah Saw. Hukum mereka menurut mayoritas para ulama dan ahli hadis adalah seperti kelompok pembelot. Keempat, kaum muslimin yang membelot dari imam, tetpai tidak berpendapat seperti khawārij yang menghalalkan darah umat Islam dan menawan anak-anak mereka. Mereka termasuk para pembelot (Humam, t.th.: 334).

Ibnu Nujaim mendefinisikan pemberontakan sebagai berikut; kaum muslimin yang membelot dari imam/pemimpin yang adil, tapi mereka tidak menghalalkan darah kaum muslimin dan menawan anak-anak mereka seperti yang dilakukan oleh orang-orang khawarij (Nujaim, t.th.: 151). 
ljtihad, Jurnal Wacana Hukum Islam dan Kemanusiaan, Volume 16, No. 1, Juni 2016: 67-83

Kita dapat mengetahui dalam beragam definisi dan penjelasan diatas, bahwa mereka yang melakukan pemberontakan dan terorir terhadap warga kaum muslimin dan pemerintah yang sah tdak boleh diampuni. Sebab tujuan pembelot adalah penghancuran terhadap kekuatan, kekuasaan dan stabilitas serta keselamatan bangsa. Bahaya pemberontakan melawan pemerintah muslim dapat difahami dengan jelas dalam Q.S.al-Maidah [5]: 33;

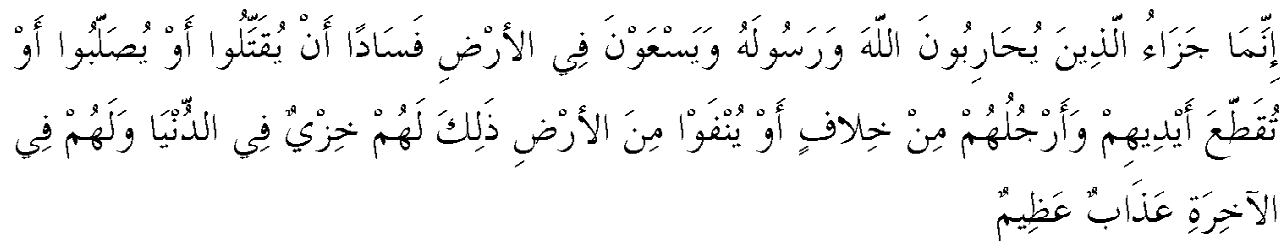

"Sesungguhnya pembalasan terhadap orang-orang yang memerangi Allah dan RasulNya dan membuat kerusakan di muka bumi, hanyalah mereka dibunuh atau disalib, atau dipotong tangan dan kaki mereka dengan bertimbal balik, atau dibuang dari negeri (tempat kediamannya). Yang demikian itu (sebagai) suatu penghinaan untuk mereka di dunia, dan di akhirat mereka beroleh siksaan yang besar".

Ayat ini mengindikasikan bahwa yang bertanggungjawab untuk mengiliminir mereka yang meneror masyarakat dengan aktivitas militansi dan kekerasan adalah negara. Terlepas dari apapun keyakinan yang hendak mereka tegakkan. Dalam menafsirkan ayat tersebut di atas. (Katsir, 1401H: 51). Ibnu 'Abbas mengatakan bahwa barangsiapa yang mengangkat senjata di wilayah Islam dan melakukan teror di jalanan kemudian imam mampu mengalahkan dan menundukkannya, maka imam boleh memilih antara membunuh, menyalib atau memotong tangan dan kakinya.

Ayat ini juga mengindikasikan bahwa hukuman mati itu sangat konstitusional. al-Qa $>$ dhi Tsanā Allāh Pānipati menuliskan para ulama telah bersepakat bahwa yang dimaksud dengan kelompok yang memerangi dan melakukan kerusakan dalam ayat ini adalah para perampok. Baik mereka itu dari kalangan kaum muslimin ataupun kafir dzimmi. Para ulama juga telah bersefakat bahwa siapa saja yang mengangkat senjata sambil melakukan teror dan penyerangan di luar perkotaan yang jauh dari jangkauan keamanan, maka dia adalah muba>rib (pelaku teror) dan perampok yang diberlakukan padanya hukuman dalam ayat ini (Panipati, t.th.: 86). 


\section{Pemberontakan menurut pakar hukum kontemporer}

Pertemuan ke-16 Liga Muslim Dunia (The Muslim World League) yang diselenggarakan di Universitas Hukum Islam Mekah tanggal 5-10 Januari 2002 langsung di bawah supervise Raja Fahd bin 'Abdu Al-Aziz, al-Khadim al-Haramain mendefinisikan terorisme sebagi berikut;

Terorisme adalah agresi yang dilakukan oleh individu atau kelompok, terhadap negara, agama, darah, akal, atau kehormatan seseorang. Teror mencakup aksi menakut-nakuti, menyakiti, mengancam, membunuh tanpa sebab apapun. Teror juga bertujuan menimbulkan ketakutan di masyarakat, dengan cara menyakiti, mengancam kehidupan, kebebasan, keamanan mereka. Di antara bentuk teror bisa berupapengrusakan lingkungan atau salh satu properti privat dan publik serta sumber daya alam dan nasional. Semua ini adalah bentuk kerusakan di muka bumi yang dilarang oleh Allah sebagaimana dalam QS.Al-Qașaș [28]:77. Sungguh Allah swt telah menetapkan balasan tegas terhadap terorisme, agresi, dan kerusakan. Allah swt menyatakan sebagai bentuk peperangan melawan Allah Swt dan RasulNya.

Tidak ada satupun undang-undang hasil manusia yang memiliki sanksi tegas semacam ini berkenaan dengan bahaya terorisme. Syariat Islam menganggapnya sebagai perang melawan hukum dan makhluk Allah. Undang-undang ini menegaskan bahwa di antara contoh terorisme adalah teror yang dilakukan negara. Contoh kongkrit akan hal ini adalah bangsa Serbia yang menyerang terhadap penduduk Bosnia Herzegovina dan Kosovo. Undangundang ini juga berpendapat bahwa teror ini adalah bentuk yang paling kejam karena mengancam keamanan dan perdamaian dunia. Melawan dan mencegah hal itu termasuk jihad di jalan Allah Swt.

Ibnu Humam menyatakan bahwa terorisme sama saja dengan memerangi Allah dan Rasulul-Nya serta umat Islam. Para perompok dinamakan kelompok yang memerangi Allah Swt. karena para musafir selalu bertawakal kepada Allah. Maka orang yang melenyapkan rasa aman dengan memerangi orang-orang yang bertawakal kepada Allah Swt. termasuk teroris. Adapun yang dinamakan memerangi Rasul-Nya, maka itu bisa dilihat dari aspek melanggar perintahnya dan bisa juga dilihat dari aspek bahwasanya Rasul adalah yang menjaga rasa aman umat Islam di perjalanan. Demikian juga para khalifah dan raja-raja 
ljtihad, Jurnal Wacana Hukum Islam dan Kemanusiaan, Volume 16, No. 1, Juni 2016: 67-83

sebagi pengganti sepeninggalnya. Siapa saja yang mengganggu rasa aman di perjalanan yang telah dijamin oleh Rasul dan para penggantinya, maka sungguh dia telah memerangi Allah Swt. (Humam, 1988: 303).

Pendapat-pendapat yang telah disebutkan ini membuktikan bahwa terorisme sama saja dengan menabuh genderang perang melawan Allah, Rasulullah dan umat Islam.

\section{Status hukum melawan pemerintah zalim}

Syariah Islam telah memberikan penjelasan tegas bahwa pemberontakan bersenjata melawan pemerintah muslim tidak dapat dibenarkan, meskipun pemerintah telah melakukan kesalahan dan kezaliman. Kecuali jika Pemerintah secara terang-terangan telah menyatakan kekafirannya. Atau menurut Ijma' (kesepakatan) umat secara mutlak mengatakan bahwa pemerintah telah kafir, atau pemerintah telah menghalalkan sesuatu yang diharamkan oleh syariah dan sebaliknya. Atau Pemerinth telah menghalangi umat Islam dalam melaksanakan ibadah. Pemerintah seperti ini barulah layak disebut sebagai kufran bawwaban (nyata-nyata kafir). Hal ini juga didukung oleh hadis dimana Ibnu Hajar Al-Asqalani berkata;

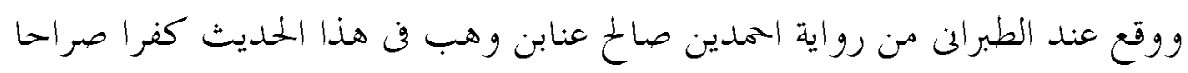

"Menurut Imam Al-Thabrani dari riwayat Ahmad bin Shaleh dari Ibnu Wahab dalam hadis ini terdapat kalimat kekafiran yang sangat jelas" (al-Asqalani, t.th.: 8).

Ini artinya, revolusi melawan pemerintah muslim harus diizinkan sacara legal sesuai aturan syari'ah ketika secara mutlak telah disepakati kekafiran Pemerintah dan tidak ada ruang bagi kemungkinan justifikasi alternatif bagi aksi Pemerintah itu. Lebih jauh Ibnu Hajar menjelaskan,

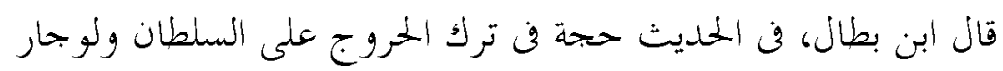

"Ibnu Bammal berkata, "Terdapat hujjah di dalam hadis ini untuk tidak membelot dari sultan (pemimpin) walaupun zalim."

Oleh sebab itu, meskipun Pemerintah telah salah dan zalim, pemberontakan bersenjata secara keras sangatlah dilarang. Bagaimanapun juga, cara-cara damai, konstitusional, demokratis, serta cara yang sah lainnya dapat digunakan untuk melakukan perubahan. 
Aḥmad al-Qashtalāni juga menyebutkan pandangan yang sama dalam komentarnya dikitab Irshāe al-Sär'i (al-Qashtalāni, t.th: 9).

Sementara babbir Ahmad Uthmani menjelaskan pandangan yang sama dalam Fath al-Mulbim dalam judulnya, "Pemberontakan Melawan Pemerintah Korup," dia berkata.

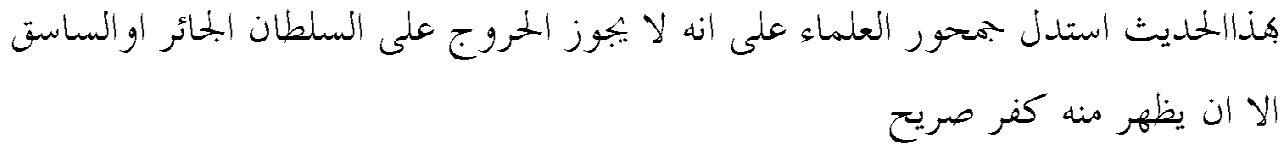

"Mayoritas para ulama berargumentasi dengan hadis ini bahwa tidak boleh membelot dari sultan yang zalim atau fasik kecuali kalau sudak nampak darinya kekafiran yang nyata." (Uthmani, 2006: 184).

\section{Pemberontakan bersenjata terhadap Muslim}

Rasulullāh menyatakan bahwa mereka yang melakukan pemberontakan bersenjata terhadap kaum muslimin tidak lagi menjadi bagian dari kaum muslimin itu sendiri. Hal ini diriwayatkan oleh Abdullah bin Umar bahwasanya Rasulullāh bersabda:

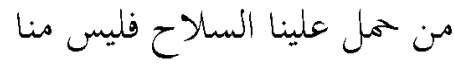

"Barangsiapa yang mengangkat senjatanya melawan kami, maka dia bukan golongan dari kami." (HR. Bukhari)

Islam bukan saja melarang mengangkat senjata, mengambil inisiatif perlawanan bersenjata terhadap Pemerintahan Islam, lebih jauh dari itu Islam menyebut bahwa aksi ini sebagai bentuk kekafiran. Islam menyatakan aksi ini sebagai hasutan dan kezaliman dimuka bumi. Tidak ada hal baik yang akan datang dari mereka sebab aksi mereka akan menciptakan kekacauan dan kerusakan sosial. Oleh sebab itu, agar berbeda dengan terorisme dan pemberontakan, seseorang harus menggunakan cara-cara damai untuk melawan pemerintah zalim dan sewenang-wenang. Jika seseorang telah memahami hal ini, maka dia akan mengerti bahwa tidak ada kontradiksi antara amar ma'ruf dan nabyi munkar dengan larangan pemberontakan bersenjata melawan penguasa. 
ljtihad, Jurnal Wacana Hukum Islam dan Kemanusiaan, Volume 16, No. 1, Juni 2016: 67-83

\section{Kritik konstitusional atas pemerintah zalim}

Walaupun penguasa Pemerintah Muslim telah melakukan kezaliman dan ketidakadilan, tetap saja pemberontakan bersenjata untuk melawan pemerintah yang sah tidak diperbolehkan. Meski demikian, larangan ini tidak berarti bahwa Pemerintah diperbolehkan untuk meneruskan kezaliman dan ketidak-adilan. Islam bukan saja memperbolehkan, bahkan menganjurkan untuk angkat bicara dan mengambil tindakan-tindakan sah untuk melawan ketidakadilan, kejahatan dan tindakan inkostitusional pemerintah, mengutuk serta menekan mereka agar terjadi perbaikan dan reformasi. Islam juga memerintahkan agar pemerintah layak diganti, jika menolak suara nasehat dan perbaikan. Meski demikian, suksesi dan transisi harus berjalan dengan cara-cara halus, damai, dan dengan proses yang menghindari cara-cara kekerasan, mengucurkan darah, atau pembunuhan. Inilah makna sebenarnya dari jihad melawan kezaliman Pemerintah. Oleh sebab itu, pembunuhan manusia dengan dalih amar ma'ruf dan nabyi munkar selamanya tidak dapat dibenarkan.

Berbicara malawan kesewenang-wenangan para penguasa telah menjadi tanggung jawab kita bersama. Karena merupakan bagian penting dari amar ma'ruf dan nabyi munkar. Hal ini tidak dilarang, bahkan sebaliknya, orang yang tidak mau melakukannya dianggap berdosa. Bedanya dengan terorisme, Islam memerintahkan kita untuk menggunakan cara-cara konstitusional, legal, dan demokratis untuk menghasilkan perubahan. Hadis di atas melarang pembunuhan, pemberontakan bersenjata, atau bahkan terorisme. Merebut beberapa wilayah, memaksakan satu pandangan kepada yang lain, menguncurkan darah, serta melakukan aksiaksi terorisme mutlak tidak diperbolehkan, bahkan pelakunya dianggap telah keluar dari Islam. Pada akhirnya akan memberikan alasan dan kesempatan pihak asing untuk melakukan campur tangan dalam urusan internal Negara Islam. Oleh sebab itu, syari'ah telah mengatur tindakan tegas agar para pemberontak dihentikan. Hal ini sesuai kata salah satu isteri nabi,Umu Salamah :

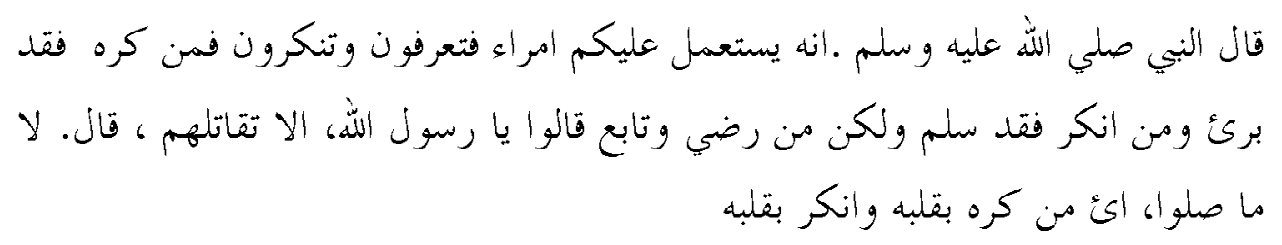


"sesungguhnya akan ada banyak pemimpin yang memerintahkan kalian. Kalian mengenal mereka, tapi kemudian mengingkarinya. Barangsiapa yang membencinya, dia akan selamat. Akan tetapi, barangsiapa yang mengikuti dan rela (maka tidak akan terbebas dan selamat). Mereka bertanya "wahai rasulullah bolehkan kami memerangi mereka?" Rasulullah menjawab, "tidak boleh, sepanjang mereka masih melaksanakan shalat.” Yaitu barangsiapa yang membenci dan mengingkari dengan hatinya.” (H.R. Muslim)

Ketika menjelaskan hadis ini Iyadh menulis dalam Ikmāl al-Mu'lim bi Fawä'id Muslim, “perkataannya, "bolehkah kami memerangi mereka?” nabi menjawab, "tidak boleh, selama mereka masih melaksanakan solat." Seperi yang telah disebutkan yaitu larangan membelot dari para pemimpin dan tetap taat kepada mereka selama mereka masih muslim dan selama mereka tidak menampakkan kekafiran yang nyata. Isyarat dalam hadis ini adalah selama mereka masih melaksanakan shalat. Yaitu selama masih berlaku atas mereka hukum orang yang menghadap kiblat dan melaksanakan shalat, selama tidak murtad dan tidak mengganti agama islam serta mengajar kepada agama selain islam. Ada isyarat (dalam hadis ini), yaitu sabda Nabi, "Hamba sahaya Habasyi (Etiopia) yang memimpin kalian dengan kitab Allah. Yaitu dengan Islam dan hokum kitabullah walaupun zalim” (Iyadh, 1998: 254-265).

Lebih jauh dia menjelaskan, "akan tetapi barangsiapa yang rela mengikuti," maknanya: Akan tetapi dosa dan siksanya atas (akan ditimpakan kepada) orang yang rela dan mengikuti. Terdapat dalil dalam hadis ini bahwa sesungguhnya orang yang tidak mampu melenyapkan kemungkaran, maka tidak akan berdosa karna dia bersikap diam. Akan tetapi, apabila dia rela atau tidak membenci dengan hatinya atau mengikuti (kemungkaran tersebut), maka dia akan berdosA. Adapun perkataannya "Apakah kami boleh memerangi mereka?" Nabi menjawab, “Tidak, selama mereka masih melaksanakan shalat," mengandung makna seperti yang telah lalu, yaitu tidak boleh membelot dari khilafah dengan alasan kezaliman dan kefasikannya, selama merek tidak mengubah kaidah-kaidah Islam.”

Auf bin Malik mengatakan bahwa Rasulullah bersabda, "pemimpin yang baik adalah orang-orang yang kalian mencinti mereka dan merekapun mencintai kalian, mereka mendoakan kebaikan bagi kalian dan kalianpun mendoakan kebaikan bagi mereka. Adapun pemimpin yang buruk adalah orang-orang yang kalian membenci mereka dan merekapun membenci kalian, kalian melaknat mereka dan mereka pun melaknat kalian. Ditanyakan, "Wahai Rasulullah, bolehkan kami memerangi mereka dengan pedang?” Nabi menjawab, "tidak 
ljtihad, Jurnal Wacana Hukum Islam dan Kemanusiaan, Volume 16, No. 1, Juni 2016: 67-83

boleh, selama mereka melaksanakan shalat diantara kalian. Jika kalian melihat pemerintahan kalian melakukan sesuatu yang kalian benci, maka bencilah perbuatannya dan jangan membelot dari ketaatan pada mereka" (HR. Muslim).

Para ulama hadis telah menjelaskan kata la tanzi'u yadan min tha'ah (jangan membelot dari taat pada mereka) berarti kita wajib menaati mereka dan dilarang keras melakukan pemberontakan senjata, kecuali mereka memerintahkan kalian untuk menjadi kafir. Sedangkan sabda Rasulullah, "Selama mereka melaksanakan shalat diantara kalian." Adalah ungkapan metaforis (isti'arah) yang menunjukan mereka adalah penguasa muslim. Hal ini tidak berarti bahwa mereka harus melakukan shalat lima waktu, bertindak shaleh atau takut kepada Allah.

Dalil yang menunjukan argumentasi ini terdapat dalam hadis tersebut, yaitu ungkapan syirar a'immatikum (pemimpin yang buruk) nampak bagi kita dari ungkapan "kalian membenci mereka dan merekapun membenci kalian"yaitu dikarenakan tindakan yang sewenang-wenang, perbuatan jahat, dan ketidakadilan yang mereka lakukan. Kita tidak bisa mengatakan bahwa pemimpin jenis ini adalah mereka yang shalat lima waktu teratur dan selalu melaksanakan shaum (Ramadhan). Jika tidak begitu, mereka tidak akan diberi stigma oleh Rasulullah sebagai pemimpin yang buruk.

Oleh sebab itu, kepada penguasa yang diungkapkan Rasulullah dengan sabdanya, "selama mereka melaksanakan shalat diantara kalian." Maksudnya adalah muslim- meskipun perlambang kata-kata dan bukan perbuatannya terlarang melakukan pemberontakan bersenjata melawan mereka.

Imam al-Qurthubi telah menjelaskan kata-kata ini dalam al-Mufbim limä ushkila min Talkbìs Kitāb Muslim, sebuah komentar terhadap Shahih Muslim. Dia berkata, "sebagaimana telah Rasulullah jelaskan bahwa mereka yang shalat adalah muslim berdasarkan sabdanya, "aku dilarang membunuh mereka yang shalat." Artinya, mereka adalah orang-orang muslim. Oleh sebab itu, makna seperti yang saya sebutkan diatas dapat dipergunakan disini (alQurmubi, 1372H: 54).

Imam al-Tirmidhi meriwayatkan sebuah hadis dari Ummu Salamah dalam kitab Sunannya: 


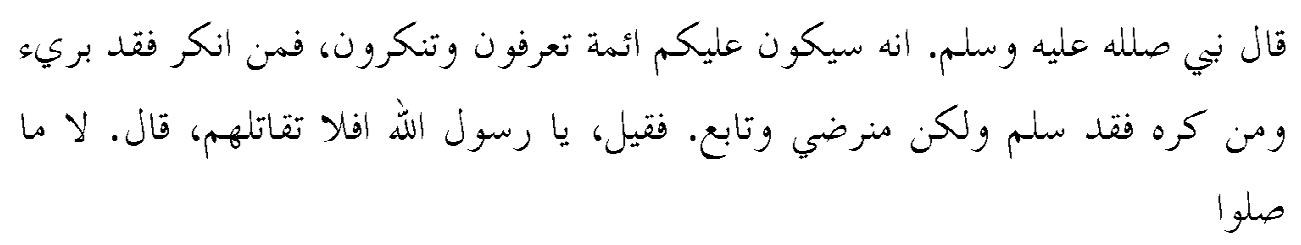

"Sesungguhnya akan ada pemimpin-pemimpin yang memerintahkan kalian. Kalian mengenal mereka, (tapi) kalian mengingkari mereka. Barangsiapa yang mengingkari, dia telah terbebas dan barangsiapa yang membenci, dia telah selamat. Akan tetapi, barangsiapa yang rela dan mengikuti." Maka ditanyakan, "wahai Rasulullah, bolehkan kami memerangi mereka? "Nabi menjawab,"tidak, selama mereka melaksanakan shalat" ( H.R. alTirmidhi).

Berkenaan dengan hadis ini, 'Abdu al-Rahman Al-Mubarakfuri, menulis,

"Bolehkah kami memerangi mereka? "Nabi menjawab, "Tidak boleh." Maksunya : janganlah kalian memerangi mereka, selama mereka melaksanakan shalat. Sesungguhnya Rasulullāh melarang memerangi mereka selama mereka melaksanakan shalat yang merupakan pokok ajaran islam sebagai bentuk tindakan preventif dari merebaknya fitnah dan perselisihan" (al-Mubarakfuri, t.th.: 138).

Artinya bahwa orang muslim telah dijamin secara sah oleh syariat mnggunakan perjuangan konstitusional dan demokratis dengan cara-cara damai dengan memperlihatkan kesabaran dan kesungguhan melawan ketidakadilan para penguasa. Dengan demikian, konflik, pertumpahan darah, pembantaian dikalangan umat islam dapat dihindari dan pemberontakan bersenjata dapat digagalkan.

Dalam Sunan Abu Dawud, ada sebuah riwayat yang disampaikan Dabba bin Mihsan melalui Ummu Salamah, Ummu Al-Mukminin, "Rasululla>h bersabda,

Akan ada pemimpin-pemimpin yang memerintah kalian. Kalian mengenal mereka, (tapi) kalian mengingkari mereka. Barangsiapa yang mengingkari, Abu Dawûd berkata, "Hisyam berkata, "Dengan lisannya," maka dia akan terbebas. Barangsiapa yang membenci mereka dengan hatinya, maka dia akan selamat. Akan tetapi barangsiapa yang rela dan mengikuti. Ditanyakan kepada Rasulullah, "wahai Rasulullah, bolehkah kami membunuh mereka? "Ibnu Dawûd berkata, "Bolehkah kami memerangi mereka?" Nabi menjawab, Tidak, selama mereka melaksanakan shalat” (H.R. Abu Dawud). 
ljtihad, Jurnal Wacana Hukum Islam dan Kemanusiaan, Volume 16, No. 1, Juni 2016: 67-83

Hadis ini serta penjelasannya menggambarkan dua poin penting secara khusus. Pertama, revolusi bersenjata terhadap penguasa muslim adalah terlarang. Tujuannya yaitu untuk menghindari kekacauan massal, pertumpahan darah, dan pembunuhan massal, walaupun pada kenyataannya para penguasa muslim itu telah melakukan kesalahan, penyimpangan, kesewenang-wenang, dan ketidak adilan. Ada beberapa cara damai yang bisa membawa kembali penguasa keliru ini ke jalan yang benar. Kedua, larangan ini akan berlaku ketika para penguasa tersebut secara terang-terangan memaksa rakyatnya untuk melakukan syirik atau memperlihatkan secara terbuka kemurtadannya. Jika sebuah kelompok hendak menggulingkan pemerintah yang sah meski atas nama menegakkan syari'ah maka menjadi perlu bahkan wajib negara menghancurkan gerakan ini dengan sekuat tenaga.

Para perampok jalanan dan para bandit dapat dideklarasikan sebagai pemberontak yang harus dihukum mati berdasarkan ayat dalam QS. al-Maidah [5]:33.

Terorisme hari ini adalah sebuah bentuk penyakit sosial yang menewaskan banyak warga sipil secara mengenaskan, tertekan secara psikologis, serta kelainan mental lainnya. Terorisme telah menggangu semua ranah sosial dengan menebarkan rasa takut, mereka menabur genderang melawan Allah SWT. Rasulullah saw dengan keras mengutuk pertikaian bersenjata dan menyatakan bahwa mereka telah mengotori Islam. Nabi bersabda, "mereka bukan umatku". Mereka telah menjauh dari jalan yang benar, membunuh manusia tanpa memandang bulu, kemudian mengangkat senjata untuk memberontak negara dan masyarakat sosial dalam skala besar. Rasulullah Saw. yang memberikan batasan syari'ah kepada kita.mengajurkan beberapa bentuk hukaman untuk melawan pemberontak dan pencipta kekacauan.

Rasulullah Saw. memperingatkan keras tentang pemberontakan dalam Barangsiapa yang membelot dari taat kepada imam dan memisahkan diri dari jamaah kemudian dia mati, maka dia mati dalam keadaan mati jahiliyah. Barangsiapa yang berperang di bawah panji kamuflase karena ego nasionalisme atau menyeruh kepada nasionalisme atau mendukun nasionalisme kemudian dia terbunuh, maka dia mati dalam keadaan jahiliyah. Barangsiapa yang membelot dari imām umat Islam, dia membunuh orang baik dan orang jahat serta tidak mengecualikan orang-orang mu'min dan tidak menunaikan janjinya, maka dia bukan dari golonganku dan aku bukan dari golongannya (HR. Muslim). 
Tidak seorang muslim pun yang diperbolehkan memberontak kebijakan muslim lainnya. Umat Islam diperintahkan untuk menjauhi kelompok pemberontak dan teroris yang memprovokasi dengan menebarkan hasutan dan militansi melawan pemerintah sah dari seorang negara muslim. Imam Muslim dan imam al-Bukhari meriwayatkan sebuah hadis dari Khudhaifah Ibnu al-Yaman yang berkata; orang-orang yang banyak bertanya kepada Rasulullah Saw. tentang kebaikan. Sedangkan aku justru bertanya tentang kejahatan, karena khawatir akan menimpa kepadaku. Aku bertanya, "wahai Rasulullah Saw. sesunggunya kami dahulu berada dalam kejahiliyahan, kemudian Allah swt menganugrahi kami dengan kebaikan in (Islam). Apakah setelah kebaikan ini akan ada kejahatan? Nabi menjawab Ya. Aku bertanya lagi”'apakah setelah kejahatan itu, akan ada lagi kebaikan?, Nabi menjawab, Ya dan di dalamnya akan terdapat kabut. Aku bertanya lagi, apa kabut itu?, Nabi menjawab, sebuah kaum yang mengikuti sunah yang bukan sunahku. Mereka mencari petunjuk yang bukan petunjukku. Engkau akan mengenal mereka, tetapi engkau akan mengingkarinya. Aku bertanya lagi, apakah setelah kebaikan itu akan ada kajahatan lagi?, Nabi menjawab, Ya, para penyeruh di atas pintu-pintu Jahnnam. Dan siapa yang memenuhi panggilan mereka, maka mereka akan menjerumuskannya ke dalam neraka Jahannam bersama mereka. Aku bertanya lagi, Sebutkanlah ciri-ciri mereka wahai Rasulullah Saw. Nabi menjawab, Ya, mereka adalah kelompok orang yang kulit mereka seperti kulit kita dan berbicara dengan bahasa kita. Aku bertanya lagi, apa pendapat anda jika aku mengalami hal itu?. Nabi menjawab, tetaplah pada jamaah kaum muslimin dan taati imam mereka. Aku bertanya lagi. Bagaimana jika tidak ada jamaah dan imam? Nabi menjawab, jika tidak ada jamaah dan imaa $>$ m, maka jauhilah semua kelompok itu, walaupun engkau harus menggigit akar pohon hingga meninggal dalam keadaan seperti itu.

Hadis ini menggaris bawahi beberapa pokok penting tentang apa yang sedang kita bahas saat ini. Hadis ini menyebutkan bahwa di akhir zaman, akan muncul kekacauan dan fitnah dalam umat Islam, dan mereka yang menghasut pemberontakan akan mendorong orang lain masuk ke neraka dan bukan ke syurga. Bahasa dan warna kulit, dan tampilan mereka akan seperti umat Rasulullah saw. Akan tetapi sikap mereka memusuhi mainstream umat Islam. Terlebih mereka akan meberontak melawan pemerintah muslim dan mengajak pihak lain untuk memberontak. Kita juga belajar dari hadis ini, bahwa menjauhi manusia-iblis, 
ljtihad, Jurnal Wacana Hukum Islam dan Kemanusiaan, Volume 16, No. 1, Juni 2016: 67-83

kemudian bergabung dengan jamaah muslim akan melindungi keyakinan kita. Dan yang terakhir, kita melihat bahwa cara yang dilakukan terorisme dan pemberontak bersenjata melawan pemerintah muslim berlawanan secara langsung dengan hukum Islam, bahkan mereka yang merrespon hasutan dan bergabung dengan mereka akan kekal di neraka.

\section{Kesimpulan}

Dalam ajaran Islam tidak ada satupun ayat al-Qur'an atau Hadis yang mengajarkan pemberontakan pemerintah yang sah yang berujung kepada pembunuhan jiwa seseorang tanpa alasan yang dibenarkan oleh hukum. Rekayasa dan konspirasi secara sistematis, sehingga faktanya jelas dengan adanya upaya infiltrasi kedalam kelompok Islam yang memiliki semangat perlawanan dan pemberontakan yang berujung pada penggulingan pemerintahan yang sah.

Imam empat mazhab, cukup menggambarkan bahwa ada kesepakatan yang sudah cukup dikenal berkaitan dengan larangan memberontak melawan pemerintah muslim. Merupakan tanggungjawab pemerintah untuk mengaskan otoritas dan kekuatan hukumnya, kemudian seluruh warga negara muslim harus memberikan dukungan penuh kepada pemerintah dalam upaya memberantas pemberontak bersenjata.

\section{Daftar pustaka}

'Alsqāanini, Ibnu *ajar A-mad bin 'Alì. Al-Dirarah fi Takbrij al-Ahadith al-Hidayah, Beirut: Dār al-Ma'rifah, t.th.

'Aini, Bard al-Dīn, al-Umdah al-Qàri Syarh Sha-i- al-Bukhāri: Dār Ihyā al-Turāts Al-'Arabī, t.th.

Bukhāri, Abu 'Abdi Allāh Mu-ammad bin Ismā̄îl bin Ibrāhìm bin mughïah. al-Jami' alsha-i-, Beirut: Dār Ibnu Katsìi, 1987.

Ibnu Ābidin Mu-ammad. Radd Al-mukbtar 'ala al-Durr al-Mukbtàr 'ala Tanwìr al-bshār, Beirut DārAl-Fikri, 1386.H.

Ibnu Humām, Kamāl Al-Dīn Mu-ammad bin 'Abdi Al-Wāhid. Fath al-Qađir Syarh al-Hidayah, Quetta: Muktabah Rasyidiyyah, t.th.

Ibnu Humaid. 'Abdu. al-Musnad, Kairo: Muktabah al-Sunnah, 1988.

Ibnu Mufli-, Syamsyu al-Dīn. al-Furû, Beirut: Dār al-Kutub al-Ilmiyyah, 1418.H.

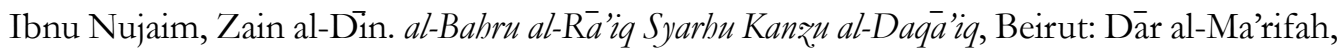
t.th. 
Nawawi, Mu-yì. Raudhat al-Thälib̄in wa Umda al-Mufliyȳin, Beirut: al-Maktab al-Islāmi, 1415. H.

Mubarakpuri, Muhammad 'Abda al-Rahman, al-Tubfah al-Abwadzi fi Syarbi Jami al-Tirmidzi. Beirut: Dar al-Kutu al-'Ilmiyyah, t.th.

Naisyaburi, Muslim al-Hajjaj. al-Jami al-Shabih, Beirut: Dar Ihya al-Turats al-Arabi, tt.

Qurthubī, Abû 'Abdi Allāh Mu-ammad bin A-mad. al-Jami li A-kam al-Qur'an, Kairo: Dār Al-Sya'b, $1372 \mathrm{H}$.

Sijistani, Abû Dawûd. al-Suñan, Beirut, Dār al-Fikri, 1994.

Tirmidzi, Abu Muhammad bin Isa. Al-Suñan, Beirut: Dār Ihya al-Turāts al-Arabī, t.th.

Yahsubi, Qadhi 'Iyadh, al-Ikmal. al-Mu’lim bi Fawaid Muslim, Beirut: Dār al-Wafa, 1998. 